\title{
Diversity, Distribution and Relative Abundance of Insect Pollinators on Apple Crop in Shimla Hills of Western Himalaya India
}

\author{
V. K. Mattu ${ }^{1}$, Dimpal Nirala ${ }^{2}$ \\ ${ }^{1}$ Sociobiology and Behavioural Ecology Research Lab \\ ${ }^{2}$ Department of Biosciences, Himachal Pradesh University, Shimla-171 005 (HP), India
}

\begin{abstract}
Diversity, distribution and relative abundance of various insect visitors of apple crop was investigated and carried out by collecting flower visitors in different orchards located at Padola (2200 m), Kalzar (2514 m) and Jarol (2648m) in Shimla hills of Western Himalaya. Insect diversity studies showed that apple flowers were visited by 41 species of insects belonging to 5 orders and 16 families of class Insecta. Of these, 13 species belonged to Hymenoptera, 17 to Diptera, 8 to Lepidoptera, 2 to Coleoptera and 1 to order Thysanoptera. Analyses of data on relative abundance of different insect visitors revealed that Indian hivebee, A. cerana was the most abundant insect visitor to apple flowers in all the three experimental orchards i.e. Padola (29.23\%), Kalzar (29.43\%) and Jarol (28.82\%). European honey bee, A. mellifera (18.59\%, $17.23 \%$ and 16.74\%) and Bombus tunicatus $(2.02 \%$, 2.04\% and 1.98\%) were other important hymenopterans at Padola, Kalzar and Jarol orchards. Besides, hymenopterans, dipterans also constituted an important group of insect pollinators.
\end{abstract}

Keywords: Insect pollinator, Relative abundance, Apple, Honeybee, Shimla hills

\section{Introduction}

Pollination provides an essential ecosystem service that contributes to the maintenance of biodiversity and ensures the survival of plant species including crop plants. For one out of every three bites eaten, one can thank a bee, butterfly, bat, bird or other pollinator. Any loss of biodiversity is a matter of public concern, but losses of pollinating insects may be particularly troublesome because of the potential effects on plant reproduction and hence on food supply security. Many agricultural crops and natural plant populations are dependent upon pollination and often on the services provided by wild, unmanaged, pollinator communities (Free, 1993; Kluser and Peduzzi, 2007).

It is estimated that about $85 \%$ of the world's flowering plant species depend upon animals, mostly insects for pollination (Ollerton et al., 2011) and the total annual economic value of crop pollination worldwide is about \$153billion (Gallai et al., 2009). Mattu (2013) emphasized that flower-visiting insects provide an important ecosystem function to global crop production through their pollination services. The rapid spread of human habitation is affecting the available natural habitats through urbanization and other land-use practices, putting pressure on ecosystem services delivered by wild pollinators. Other agronomic practices like manuring, pesticides, fertilizers etc. are quite cost effective and these may not yield the desired results without the use of managed and unmanaged pollinators for enhancing the productivity levels of different crops by pollination.

In recent years, apple has emerged as the leading cash crop amongst temperate fruit crops in Himalayan belt. It alone accounts for $48 \%$ of area under all fruits and $78 \%$ of total fruit production. The area covered under apple production increased from 35,076 ha in $1975-76$ to 99,564 ha in 2009 10 registering an annual growth of $3.14 \%$ during this period
(Singh et al., 2012). During the last few years, the production of apple per hectare has come down inspite of increase in area under apple cultivation. So, there is a need for changed strategies and look for other possible inputs such as full use of under-utilized and eco-friendly resources like bee pollination for increasing apple production in state (Verma and Jindal, 1997; Mattu et al., 2012b; Mattu and Mattu, 2013; Mattu, 2014).

Honeybees derive their food in the form of pollen and nectar, which are the raw materials of beekeeping industry. This collection of pollen and nectar from flowering plants by bees is known as 'foraging behavior'. In the Himalayan region Honey bees are the most important pollinators in apple orchards and they form a vast majority of pollinating insects (Free, 1993). However, very little is known about the role of different insect visitors including honeybees in pollinating various horticultural crops in India especially Himachal Pradesh (Mishra et al.,1976; Mattu and Verma, 1985; Verma, 1990; Kumar, 1997; Mattu and Bhagat, 2015). Therefore, present investigation was conducted in order to know the diversity, distribution and relative abundance of different insect species visiting apple crop in Shimla hills of Western Himalaya.

\section{Material and Methods}

Research investigations were carried out on diversity, distribution and relative abundance of various insect visitors of apple crop, by collecting them in different orchards located at Padola (2200 m), Kalzar (2514 m) and Jarol (2648 m) of Shimla hills of Western Himalaya. These apple orchards had more than 200 trees belonging to Golden delicious, Red delicious, Royal delicious and Red Gold varieties. All these collections were made during the months of March-April, when the orchards were in full bloom. Almost equal number of working hours were spent in each 


\section{International Journal of Science and Research (IJSR) \\ ISSN (Online): 2319-7064}

Index Copernicus Value (2013): 6.14 | Impact Factor (2015): 6.391

orchard. Relative abundance of different insect visitors was determined in terms of their visits per 500 flowers/10 minutes (Verma and Chauhan, 1985). The observations were recorded during 0900-1000, 1200-1300 and 1500-1600 hours of a day and average counts at these hours gave abundance of an insect pollinator for the particular day (Southwood, 1978). For collection of different insect species, following methods were used: Hand picking; sweeping; beating; aerial netting and aspirator method and standard methods were followed for the preservation of insect pollinators belonging to different orders such as Hymenoptera; Diptera; Lepidoptera; Coleoptera and Thysanoptera (Arora, 1990; Ghosh, 1990; Jonathan, 1990). Pollination data was analysed statistically (Snedcor and Cochran, 1993).

\section{RESULTS AND DISCUSSION}

Pollinator diversity studies showed that apple flowers were visited by 41 species of insects belonging to 5 orders and 16 families of class Insecta. Of these, 13 species belonged to Hymenoptera, 17 to Diptera, 8 to Lepidoptera, 2 to Coleoptera and 1 to order Thysanoptera (Table 1). It was observed that Hymenoptera was represented by 6 families viz., Apidae, Vespidae, Halictidae, Andrenidae, Formicidae and Pteromalidae with species like Apis cerana, A. mellifera, Bombus haemorrhoidalis, B. tunicatus, Andrena sp., Halictus dasygaster, Camponotus sp., Vespa mandarina, V. velutina etc. Of the dipterans, species like Musca domestica, Eristalis tenax, E. himalyansis, Metasyrphus corollae, Episyrphus sp., Fannia domestica, Dolichopus sp., Calliphora vicina etc. spread over families Syrphidae, Cordiluridae, Calliphoridae and Dolichopodidae were recorded as pollinators of apple crop. However, lepidopterans were represented by only 8 species belonging to families Pieridae, Nymphalidae and Noctuidae. Order Coleoptera was represented by two families i.e. Coccinellidae and Chrysomelidae. In addition, a single species of thrips belonging to order Thysanoptera was also recorded as pollinator of apple crop in Shimla hills (Table1).

Different investigators have reported different number of pollinators on various temperate fruit crops. For example, Verma and Chauhan (1985) observed 44 species of insect pollinators on apple bloom in Shimla hills, of which 16 belonged to Hymenoptera, 11 to Diptera, 9 to Lepidoptera, 7 to Coleoptera and 1 to Hemiptera. A similar survey in North Korea by Hong et al. (1989) revealed a total of 88 species of pollinators on apple, pear and peach flowers, whereas, Kumar (1997) recorded that apple flowers were visited by 49 insect species in the Himalayan belt. Similarly, Thapa (2006) observed the presence of 50 species of insect pollinators on flowers of different crops in Nepal and found that honeybees contributed $80 \%$ of the total insect pollination. Recent pollinator diversity studies by Mattu et al., (2012a) and Raj et al., (2012) also showed that apple flowers were visited by 46 species of insects belonging to 5 orders and 17 families of class Insecta.

Present studies on relative abundance of different insect visitors revealed that Indian hive bee, A. cerana was the most abundant insect visitor to apple flowers in all the three experimental orchards i.e., Padola (14.64 \pm 0.54 , 29.23\%),
Kalzar $(13.70 \pm 0.71,29.43 \%)$ and Jarol (12.68 \pm 0.64 $28.82 \%)$. Other important hymenopteans at Padola, Kalzar and Jarol were European honeybee, A. mellifera $(9.24 \pm 0.21$, $18.59 \%, 8.35 \pm 0.44,17.23 \%$ and $8.12 \pm 0.52,16.74 \%)$, Bombus tunicatus $(0.72 \pm 0.06,2.02 \%, 0.71 \pm 0.06,2.04 \%$ and $0.69 \pm 0.03,1.98 \%)$ and Vespa velutina $(0.28 \pm 0.01,0.55 \%$, $0.27 \pm 0.01,0.49 \%$ and $0.29 \pm 0.01,0.42 \%$ ) Among Dipterans, Musca domestica $(7.42 \pm 0.21,13.25 \%, 7.26 \pm 0.09,13.72 \%$ and $7.20 \pm 0.08,14.12 \%)$ and Eristalis tenax $(3.42 \pm 0.09$, $4.94 \%, 3.42 \pm 0.04,4.97 \%$ and $3.42 \pm 0.08,5.02 \%$ ) were the most important pollinators at Padola, Kalzar and Jarol orchards respectively. Moreover, Heliothis armegera and Pieris canidia were important lepidopteran pollinators present at Padola $(1.62 \pm 0.05,2.42 \%$ and $0.52 \pm 0.07,0.40 \%)$, Kalzar $(1.57 \pm 0.08,2.36 \%$ and $0.50 \pm 0.02,0.41 \%)$ and Jarol $(1.52 \pm 0.19,2.44 \%$ and $0.49 \pm 0.03,1.01 \%)$ orchards, Coccinella sp. $(0.62 \pm 0.04,1.40 \%, 0.62 \pm 0.04,1.43 \%$ and $0.59 \pm 0.04,0.34 \%$ ) was the only coleopteran pollinator at Padola, Kalzar and Jarol orchards respectively. However, thrips belonging to order Thysanoptera were present at Padola $(0.79 \pm 0.04,1.38 \%)$, Kalzar $(0.82 \pm 0.02,1.68 \%)$ and Jarol $(0.74 \pm 0.03,1.57 \%)$ orchards (Tables $2-4)$.

Based on present studies it is suggested that hymenopterans and dipterans were the most abundant insect pollinators of apple at Padola $(52.00 \%, 41.00 \%)$, Kalzar $(50.76 \%, 43.05 \%)$ and Jarol $(49.42 \%, 45.60 \%)$ orchards.

These results are in conformity with the earlier observations of Mishra et al. (1976); Verma (1990) and Mattu and Mattu (2010) who also reported that honeybees constituted a major proportion of insect pollinators on apple crop in Shimla hills and wild bees also visited apple flowers in good number. Similarly, Dashad (1989) and Kumar (1997) also found the hymenopterans and dipterans as the most predominant insect species on apple crop in Shimla hills. A number of recent studies have suggested that both domesticated and wild native bees play an important role in crop pollination (Winfree et al. 2007). Recently, Mattu et al. (2012a) and Mattu and Bhagat (2015) reported Xylocopa fenestrata, Halictus sp., Bombus sp., Camponotus sp. and Vespa sp. in good proportion on apple crop in Himachal Pradesh.

Analyses of data on pollinator diversity and relative abundance of insect visitors on apple bloom it is observed that Hymenopterans were most abundant insect pollinators on apple bloom in Shimla hills of Western Himalayas. These results were in accordance with earlier findings of Mattu and Mattu (2007) who also found hymenopterans (78.89\%) as the most important insect pollinators on almond bloom, whereas, hymenopterans $(44.50 \%)$ and dipterans (49.37\%) were almost equally abundant on peach bloom in Shimla and Solan hills respectively. Present results also support the recent findings of Mattu and Bhagat (2015) who also found hymenopterans as the most important insect pollinators on apple bloom in Himachal Pradesh.

\section{ACKNOWLEDGEMENTS}

The authors are thankful to the Chairperson, Department of Biosciences, Himachal Pradesh University, Shimla for providing the necessary facilities and for encouragements.

\section{Volume 5 Issue 6, June 2016} www.ijsr.net 


\section{International Journal of Science and Research (IJSR) \\ ISSN (Online): 2319-7064}

Index Copernicus Value (2013): 6.14 | Impact Factor (2015): 6.391

\section{REFERENCES}

[1] Arora, G.S. 1990. Collection and preservation of animals (Lepidoptera). Zoological Survey of India, Calcutta, 131- 138.

[2] Dashad, S.S. 1989. Pollination studies on apple (Malus domestica Borckh) with particular reference to the role of honey bees. Ph.D. Thesis, Dr. Y.S. Parmar University of Horticulture and Forestry, Solan, H.P. India.

[3] Free, J.B. 1993. Insect Pollination of Crops. Academic Press, London, 684.

[4] Gallai, N., Salles, J.M., Settele, J. and Vaissiere, B.E. 2009. Economic valuation of the vulnerability of world agriculture confronted with pollinator decline, Ecological Economics, 68: 810 - 821.

[5] Ghosh, A.K. 1990. Collection and preservation of animals. Zoological Survey of India, Calcutta, 71-80.

[6] Hong, K.J., Lee, S.H. and Choi, K.M. 1989. Flower visiting insects on the flowers of pear, peach and apple trees in Suwon. Korean. J. Apic. 4: 16-24.

[7] Jonathan, J.K. 1990. Collection and preservation of animals (Hymenoptera). Zoological Survey of India, Calcutta, 147-150.

[8] Kluser, S. and Peduzzi, P. 2007. Global Pollinator Decline: A Literature Review, UNEP/GRID Europe, UNEP.

[9] Kumar, L. 1997. Foraging ecology and behaviour of Apis cerana F. and Apis mellifera L. in pollinating apple and cherry flowers. Ph.D Thesis, Himachal Pradesh University, Shimla, India.

[10] Mattu, Neelam and Mattu, V.K. 2010. Pollinator Diversity, Beekeeping and Sustainable Mountain Crop Productivity. In "Advances in Entomology” (ed. Singh, J and Kumar, A). New Delhi: Kanishka Publishers, pp.37-51.

[11] Mattu, V.K. 2013. Pollinator Friendly Management Practices in Himachal Himalayas. In "Vignettes of Himachal Himalayas- Vol 2". Satyam Publishing House, New Delhi, pp 75-99.

[12] Mattu, V.K. 2014. Role of honeybees and other pollinators in crop productivity and impacts of climate change. Wkshp. on Promotion of Honey Beekeeping in Haryana, Panchkula, pp. 56-74.

[13] Mattu, V.K. and Bhagat, T. 2015. Pollinator diversity and relative abundance of insect visitors on apple crop in Kullu hills of Western Himalaya, India. International Journal of Scientific Research. 4(6): 264268.

[14] Mattu, V.K. and Mattu, N. 2007. Conservation and Management of Pollinators for Sustainable Horticulture in Himachal Himalaya. Institute of
Integrated Himalayan Studies (UGC Centre of Excellence), HP Univ., Shimla. 128 pages.

[15] Mattu, V.K. and Mattu, N. 2013. Mountain perspectives and modern Beekeeping Technology. Himalayan Studies Journal 4: 103-114.

[16] Mattu, V.K. and Verma, L.R. 1985. Studies on annual foraging cycle of Apis cerana indica $\mathrm{F}$. in Shimla hills of northwest Himalayas. Apidologie 16: 1-18.

[17] Mattu, V.K., Hem Raj and Mattu, N. 2012a. Pollinator diversity and relative abundance studies on apple crop in Shimla Hills, Himachal Pradesh. HP Univ. J. 1(2): 130-135.

[18] Mattu, V.K., Hem Raj and Thakur, M.L. 2012b. Foraging behavior of honeybees on apple crop and its variation with altitude in Shimla Hills of Western Himalaya, India. International Journal of Science and Nature 3(1): 296-301.

[19] Mishra, R.C., Dogra, G.S. and Gupta, P.R. 1976. Some observations on insect pollinators of apple. Indian Bee J. 38: 20-22.

[20] Ollerton, J., Winfree, R. and Tarrant, S. 2011. How many flowering plants are pollinated by animals? Oikos, 120: 321-326.

[21] Raj, H., Mattu, V.K. and Thakur, M.L. 2012. Pollinator diversity and relative abundance of insect visitors on apple crop in Shimla hills of western Himalaya, India. International Journal of Science and Nature 3 (3): 507-513.

[22] Singh, R., Vaidya, C.S. and Saraswat, S.P. 2012. Impact of high density apple plantation under horticulture in Himachal Pradesh. Agro Economic Research Centre, H.P. University, Shimla, 114 pp.

[23] Snedcor, G.W. and Cochran, W.G. 1993. Statistical methods. Oxford and IBH Publishing Company, New Delhi.

[24] Southwood, T.R.E. 1978. Ecological methods. Chapman and Hall, London.

[25] Thapa, R.B. 2006. Honeybees and other insect pollinators of cultivated plants: A review. J. Inst. Agric. Anim. Sci. 27:1-23.

[26] Verma, L.R. 1990. Beekeeping in integrated mountain development: Economic and Scientific perspectives. Oxford and IBH Publ., New Delhi.

[27] Verma, L.R. and Chauhan, P. 1985. Distribution, abundance and diversity of insect pollinators in apple orchards of Shimla hills. Indian J. Ecol. 12: 286-292.

[28] Verma, L.R. and Jindal, K.K. 1997. Fruit crops pollination. Kalyani Publishers, Ludhiana, India.

[29] Winfree, R., Williams, N.M., Duschoff, J. and Kremen, C. 2007. Native bees provide insurance against ongoing honeybee losses. Ecology Letters 10: 1105113 . 


\section{International Journal of Science and Research (IJSR) \\ ISSN (Online): 2319-7064}

Index Copernicus Value (2013): 6.14 | Impact Factor (2015): 6.391

Table 1: Insect species visiting apple flowers with their taxonomic status

\begin{tabular}{|c|c|c|c|c|}
\hline Order HYMENOPTERA & Order DIPTERA & Order LEPIDOPTERA & Order COLEOPTERA & $\begin{array}{c}\text { Order } \\
\text { THYSANOPTERA }\end{array}$ \\
\hline $\begin{array}{l}\text { Family Apidae } \\
\text { 1. Apis cerana } \\
\text { 2. Apis mellifera } \\
\text { 3. Bombus tunicatus } \\
\text { 4. Bombus haemorrhoidalis } \\
\text { 5. Xylocopa } \text { sp. } \\
\text { Family Vespidae } \\
\text { 6. Vespa mandarina } \\
\text { 7. Vespa velutina } \\
\text { 8. Polistes maculipennis } \\
\text { Family Halictidae } \\
\text { 9. Halictus dasygaster } \\
\text { 10. Halictus sp. } \\
\text { Family Andrenidae } \\
\text { 11. Andrena } \text { sp. } \\
\text { Family Formicidae } \\
\text { 12. Camponotus sp. } \\
\text { Family Pteromalidae } \\
\text { 13. Chalcid sp. }\end{array}$ & $\begin{array}{l}\text { Family Syrphidae } \\
\text { 14. Eristalis tenax } \\
\text { 15. Eristalis himalayensis } \\
\text { 16. Eristalis cerealis } \\
\text { 17. Eristalis } \\
\text { angustimarginalis } \\
\text { 18. Eristalis arvorum } \\
\text { 19. Metasyrphus corolla } \\
\text { 20. Episyrphus sp } \\
\text { 21. Scaeva pyrastri } \\
\text { 22. Melanostoma } \text { sp. } \\
\text { Family Cordiluridae } \\
\text { 23. Musca domestica } \\
\text { 24. Musca } \text { sp. } \\
\text { 25. Fannia domestica } \\
\text { 26. Orthelia } \text { sp. } \\
\text { 27. Scathophaga } \\
\text { stereoraria } \\
\text { Family Calliphoridae } \\
\text { 28. Calliphora vicina } \\
\text { 29. Lucilia } \text { sp. } \\
\text { Family Dolichopodidae } \\
\text { 30. Dolichopus } \text { sp. }\end{array}$ & $\begin{array}{l}\text { Family Pieridae } \\
\text { 31. Pieris canidia } \\
\text { 32. Pieris sp. } \\
\text { Family Nymphalidae } \\
\text { 33. Pyrameis indica } \\
\text { 34. Vanessa cashmirensis } \\
\text { 35. Neptis } \text { sp. } \\
\text { Family Noctuidae } \\
\text { 36. Heliothis sp. } \\
\text { 37. Agrotis flammatra } \\
\text { 38. Agrotis } \mathrm{sp} \text {. }\end{array}$ & $\begin{array}{l}\text { Family Coccinellidae } \\
39 . \quad \text { Coccinella } \\
\text { septumpunctata } \\
\text { sFamily } \\
\text { Chrysomelidae } \\
\text { 40. Altica } \text { sp. }\end{array}$ & $\begin{array}{l}\text { Family Thripidae } \\
\text { 41. Thrips }\end{array}$ \\
\hline
\end{tabular}

Table 2: Relative abundance of different insect pollinators visiting apple bloom at Padola orchard No. of insects $/ 500$ flowers $/ 10$ minutes

\begin{tabular}{|c|c|c|c|c|c|}
\hline Family & Genus/Species & Mean \pm S.E. & Percentage Population & Family Percentage & Order Percentage \\
\hline \multicolumn{6}{|l|}{ HYMENOPTERA } \\
\hline \multirow[t]{4}{*}{ Apidae } & Apis cerana & $14.64 * \pm 0.54$ & 29.23 & 50.91 & 52.00 \\
\hline & Apis mellifera & $9.24 \pm 0.21$ & 18.59 & & \\
\hline & Bombus tunicatus & $0.72 \pm 0.06$ & 2.02 & & \\
\hline & Bombus haemorrhoidalis & $0.59 \pm 0.02$ & 1.07 & & \\
\hline Formicidae & Camponotus sp. & $0.21 \pm 0.03$ & 0.54 & 0.54 & \\
\hline Vespidae & Vespa velutina & $0.28 \pm 0.01$ & 0.55 & 0.55 & \\
\hline \multicolumn{6}{|l|}{ DIPTERA } \\
\hline Cordyluridae & Musca domestica & $7.42 \pm 0.21$ & 13.25 & 13.25 & \\
\hline \multirow[t]{4}{*}{ Syrphidae } & Eristalis anqustimarginalis & $4.03 \pm 0.14$ & 7.19 & & 41.00 \\
\hline & Episyrphus sp. & $3.33 \pm 0.11$ & 5.00 & 2.03 & \\
\hline & Eristalis tenax & $3.42 \pm 0.09$ & 4.94 & & \\
\hline & Eristalis himalayensis & $2.21 \pm 0.08$ & 4.90 & & \\
\hline \multirow[t]{2}{*}{ Calliphoridae } & Calliphora sp. & $0.79 \pm 0.05$ & 1.35 & 2.39 & \\
\hline & Lucilia sp. & $0.59 \pm 0.03$ & 1.04 & & \\
\hline Dolichopodidae & Dolichopus sp. & $1.90 \pm 0.03$ & 3.22 & 3.22 & \\
\hline \multicolumn{6}{|l|}{ LEPIDOPTERA } \\
\hline Noctuidae & Heliothis armigera & $1.62 \pm 0.05$ & 2.42 & 2.42 & \\
\hline Pieridae & Pieris canidia & $0.52 \pm 0.07$ & 0.40 & 1.40 & \\
\hline Nymphalidae & Pyrameis indica & $0.31 \pm 0.05$ & 0.32 & 0.32 & 4.14 \\
\hline \multicolumn{6}{|l|}{ COLEOPTERA } \\
\hline Coccinellidae & Coccinella sp. & $0.62 \pm 0.04$ & 1.40 & 1.40 & 1.40 \\
\hline THYSANOPTERA & Thrips & $0.79 \pm 0.04$ & 1.38 & 1.38 & 1.38 \\
\hline
\end{tabular}

* Each value is an overall average for an insect species

S.E. $=$ Standard error about the mean

\section{Volume 5 Issue 6, June 2016} www.ijsr.net

Licensed Under Creative Commons Attribution CC BY 


\section{International Journal of Science and Research (IJSR) \\ ISSN (Online): 2319-7064}

Index Copernicus Value (2013): 6.14 | Impact Factor (2015): 6.391

Table 3: Relative abundance of different insect pollinators visiting apple bloom at Kalzar orchard.

No. of insects/500 flowers/10 minutes

\begin{tabular}{|c|c|c|c|c|c|}
\hline Family & Genus/Species & Mean \pm S.E. & Percentage Population & Family Percentage & Order Percentage \\
\hline \multicolumn{6}{|l|}{ HYMENOPTERA } \\
\hline \multirow[t]{4}{*}{ Apidae } & Apis cerana & $13.70 \pm 0.71$ & 29.43 & & \\
\hline & Apis mellifera & $8.35 \pm 0.44$ & 17.23 & 49.82 & 50.76 \\
\hline & Bombus tunicatus & $0.71 \pm 0.06$ & 2.04 & & \\
\hline & Bombus haemorrhoidalis & $0.62 \pm 0.01$ & 1.12 & & \\
\hline Formicidae & Camponotus sp. & $0.15 \pm 0.02$ & 0.45 & 0.45 & \\
\hline Vespidae & Vespa velutina & $0.27 \pm 0.01$ & 0.49 & 0.49 & \\
\hline \multicolumn{6}{|l|}{ DIPTERA } \\
\hline Cordyluridae & Musca domestica & $7.26 \pm 0.09$ & 13.72 & 13.72 & \\
\hline \multirow[t]{4}{*}{ Syrphidae } & Eristalis anqustimarginalis & $3.97 \pm 0.12$ & 7.37 & & \\
\hline & Episyrphus sp. & $3.42 \pm 0.09$ & 6.10 & & 43.05 \\
\hline & Eristalis tenax & $3.42 \pm 0.04$ & 4.97 & 23.34 & \\
\hline & Eristalis himalayensis & $2.24 \pm 0.09$ & 4.90 & & \\
\hline \multirow[t]{2}{*}{ Calliphoridae } & Calliphora sp, & $0.77 \pm 0.02$ & 1.42 & 2.44 & \\
\hline & Lucilia $\mathrm{sp}$, & $0.50 \pm 0.01$ & 1.02 & & \\
\hline Dolichopodidae & Dolichopus sp. & $1.95 \pm 0.06$ & 3.55 & 3.55 & \\
\hline \multicolumn{6}{|l|}{ LEPIDOPTERA } \\
\hline Noctuidae & Heliothis armigera & $1.57 \pm 0.08$ & 2.36 & 2.36 & \\
\hline Pieridae & Pieris canidia & $0.50 \pm 0.02$ & 0.41 & 0.41 & 3.08 \\
\hline Nymphalidae & Pyrameis indica & $0.31 \pm 0.02$ & 0.31 & 0.31 & \\
\hline \multicolumn{6}{|l|}{ COLEOPTERA } \\
\hline Coccinellidae & Coccinella sp. & $0.62 \pm 0.04$ & 1.43 & 1.43 & 1.43 \\
\hline THYSANOPTERA & Thrips & $0.82 \pm 0.02$ & 1.68 & 1.68 & 1.68 \\
\hline
\end{tabular}

* Each value is an overall average for an insect species

S.E. $=$ Standard error about the mean

Table 4: Relative abundance of different insect pollinators visiting apple bloom at Jarol orchard.

No. of insects $/ 500$ flowers/10 minutes

\begin{tabular}{|c|c|c|c|c|c|}
\hline Family & Genus/Species & Mean \pm S.E. & Percentage Population & Family Percentage & Order Percentage \\
\hline \multicolumn{6}{|l|}{ HYMENOPTERA } \\
\hline \multirow[t]{4}{*}{ Apidae } & Apis cerana & $12.68 \pm 0.64$ & 28.82 & & \\
\hline & Apis mellifera & $8.12 \pm 0.52$ & 16.74 & 48.60 & 49.42 \\
\hline & Bombus tunicatus & $0.69 \pm 0.03$ & 1.98 & & \\
\hline & Bombus haemorrhoidalis & $0.59 \pm 0.02$ & 1.06 & & \\
\hline Formicidae & Camponotus sp. & $0.11 \pm 0.03$ & 0.40 & 0.40 & \\
\hline Vespidae & Vespa velutina & $0.29 \pm 0.01$ & 0.42 & 0.42 & \\
\hline \multicolumn{6}{|l|}{ DIPTERA } \\
\hline Cordyluridae & Musca domestica & $7.20 \pm .08$ & 14.12 & 14.12 & \\
\hline \multirow[t]{4}{*}{ Syrphidae } & Eristalis anqustimarginalis & $3.77 \pm 0.08$ & 7.49 & & \\
\hline & Episyrphus sp. & $3.31 \pm 0.11$ & 5.55 & & 45.60 \\
\hline & Eristalis tenax & $3.42 \pm 0.08$ & 5.02 & 22.98 & \\
\hline & Eristalis himalayensis & $2.21 \pm 0.06$ & 4.92 & & \\
\hline \multirow[t]{2}{*}{ Calliphoridae } & Calliphora sp, & $1.83 \pm 0.05$ & 3.84 & 5.26 & \\
\hline & Lucilia sp, & $0.48 \pm 0.02$ & 1.42 & & \\
\hline Dolichopodidae & Dolichopus sp. & $1.70 \pm 0.04$ & 3.24 & 3.24 & \\
\hline \multicolumn{6}{|l|}{ LEPIDOPTERA } \\
\hline Noctuidae & Heliothis armigera & $1.52 \pm 0.19$ & 2.44 & 2.44 & \\
\hline Pieridae & Pieris canidia & $0.49 \pm 0.03$ & 1.01 & 1.01 & 3.76 \\
\hline Nymphalidae & Pyrameis indica & $0.29 \pm 0.02$ & 0.31 & 0.31 & \\
\hline \multicolumn{6}{|l|}{ COLEOPTERA } \\
\hline Coccinellidae & Coccinella sp. & $0.59 \pm 0.04$ & 0.34 & 0.34 & 0.34 \\
\hline THYSANOPTERA & Thrips & $0.74 \pm 0.03$ & 1.57 & 1.57 & 1.57 \\
\hline
\end{tabular}

* Each value is an overall average for an insect species

S.E. $=$ Standard error about the mean

Volume 5 Issue 6, June 2016 www.ijsr.net

Licensed Under Creative Commons Attribution CC BY 